Н.В.Барна,

кандидат філософських наук,

доцент, директор Інституту філології та масових комунікаиій ВМУРоЛ «Україна»

\title{
ГЕНЕРАТИВНІ ТЕНДЕНЦІЇ ДИЗАЙНУ В КОНТЕКСТІ ТЕХНО-ІННОВАЦЙ ПОСТМОДЕРНУ
}

Симбіоз - це життєва настанова, яка відрізняється від синтезу мистецтв, від ідеацій, від ритуалізації. Тут є домінанта біонічних начал, начал життєвих, простіше - примітивних, повсякденних, домінанта тієї зануреності в побут, яка домінує в тій чи іншій культурі. Тобто постмодерна практика всього величезного праксису культури - це, передусім, занурення в життя, в побут, в ту реальність, яка $\epsilon$ реальністю повсякденного буття, щоденнного існування людини. Ми намагалися зрозуміти, що цей симбіоз відбувається як жанрова єдність за домінантою деструкції, декомпозиції, деконструкції, як певна суперінсталяція за домінантою певних архітипів або ідолів культури, які ми визначили теж як символіку, міфологічних ознак жанру - фото, кіно та віртуальної реальності. Жанрів не в їх прямому розумінні, а як моделюючий принцип, відповідний тій чи іншій поетичній настанові.

Постмодерні деструктивні елементи пов'язані 3 первинним монізмом еклектики, з фотографічністю, або дискретно-монадною реальністю, що відіграє дуже велику роль. Це - намагання розкадрувати, провести горизонталь, вертикаль, вивести текстові означальні і за цими означальними побачити щось, що існує поза текстом. Це - декомпозиція як рушійність, потік, який виникає як єднання на засадах руйнування попередньої цілісності і утворення нової композиції. Усе це в постмодерні відбувається як регенерація, реконструкція авангарду, як певне підживлення і ігрова системотехніка, коли, наприклад, беруть проект К. Малевича, Е.Лисицького чи Л.Хідекеля, і вже у нових конфігураціях він стає іншим образом, іншою реальністю. Це вже virtus, кентавр породженого і породжувального принципів, це інтерактивність, підвищена відкритість і водночас тотальна дотичність до абсолюту. Це деконструкція як перевтілення, переструктурування, нова єдність як ігрова, амбівалентна, полівалентна структура, яка не просто грається з фрагментами композиційних 
структур, а перевтілює їх в абсолютно нову конфігурацію, конфігурацію постмодерного типу.

Усе це є симбіоз модерної і постмодерної практики. Постмодернізм, розгорнутий у певних візуальних реаліях, можна визначити як асамбляж - картинне мізансценування реальності, інсталяцію, про що вже йшлося, мистецький менеджмент, тобто опосередкування впливів митця і наглядача. Виникнення названих зон комунікації, де глядач вживлюється в цей простір і стає персоніфікатором інформації як інтертекстуальної єдності художнього твору, не може формуватися на засадах монізму: він формується з безкінечної кількості складових.

Ця системна, або надсистемна, єдність говорить про те, що виникає складна партитура мистецької реальності, яка розглядається як еклектичний симбіоз. Еклектика при цьому є невпорядкованістю, більше того - в постмодерні вона стає тотальною або тоталлогічною, тобто можна з'ясувати кілька логік, поліфонію логік еклектики замість моністичного запереченя класицизму, притаманного еклектиці протомодерну. Існує поліфонія логік, яка існує як еклектика, тобто як рефлексія над рефлексією, як Бог над Богом, як людина в людині, людина поза людиною. Увесь цей антропоморфний простір ще не має ніяких образно стабільних відзнак, але відчувається як спонука.

Тобто це $є$ та проективність virtus, яка надає генеративну міць формотворенню, спонукаючу міць, але поетики не надає. Поетика формується в жанрах мистецьких адеквацій, як живлення не поетичного, а логічного, позатекстового абсолюту, який існує як virtus, як домінанта культуротворчості XX-XXI століть. Цей контекст міркувань, ця, скажімо, реальність рефлективного, нерефлективного еклектичного і водночас моністичного у своїх раціональних констатаціях логосу, праксису і етосу потребує адекватного аналізу, який можна назвати полісистемним, поліфонічним, компаративістським, яким завгодно, але таким, який не може бути моністично означеним. Не може бути зорієнтованим на якусь одну парадигму, на якусь одну прерогативу того чи іншого бачення світу.

Має бути розмаїття бачень, розмаїття практик, теоретичних, рефлективних систем, які б осягли саме цю еклектику як цілісність, як надсистемну, полісистемну і підсистемну єдність, котра формується в контексті постмодерної культури. Важливо з'ясувати, що саме перекомбінування деструкції, декомпозиції, деконструкції, а також дескретної, плюральної, динамічної змішаної цілісності створює саме той феномен еклектики, який ми розглядаємо як тотальну еклектику. 
Ïї тотальність полягає в тому, що вона охоплює всі межі, всі обрії і всі можливості симбіозу або єднання. Ці межі досить прості, пов'язані $з$ тим, що їх руйнування може бути повним знищенням (це помітив М.Гайдеггер, визначивши як деструкцію). Оскільки композиція може бути членорозподільною цілісністю, доданням до попередніх традиційних практик та стратегій новітніх обріїв, новітніх просторових горизонтів, це відбулося в авангарді. Це може відбутися і в тому, що ми називаємо віртуальною реальністю (декомпозицією, деконструкцією, збиранням і розбиранням суб' єкта в кожному елементі простору, щомиті існування віртуальної реальності також).

Тут немає поетики, немає єдності, адже $є$ напівскладеність дискурсів, єдність суб'єктних настанов. Існують суб'єкти як певні інтенції, певні спонуки, які не є людьми, не є персонами, навіть не $\epsilon$ художниками або естетиками, філософами, - вони є спонукаючими реаліями, котрі утворюють ту тотальну міфологічну дійсність, яка зветься virtus. Усе це і $є$ тим загальним тлом, загальним обрієм, де виникає саме феномен постмодерністської еклектики тотальної настанови, яка відрізняється від будь-якої еклектики, що існувала в класичних та посткласичних стилях і яка існує нині як можливість співбуття естетичного досвіду. Видовище, що визначається тотальною еклектикою в постмодерні, набуває різних категорійних визначень.

Однією із фундаментальних номінацій є артефакт. Цей термін походить від археології, оскільки згодом почав позначати сучасні продукти культури, які пов'язані з арт-практиками, арт-проектами і несуть у собі можливі синтези візуальних, аудіовізуальних і просторових конотацій. Усе це певною мірою виражається в асамбляжах, інсталяціях, в акціях, хепенінгах, перформансах, у новітній музиці (так званій атональній музиці). Тобто головне полягає в тому, що сучасна культура говорить не про образ, не про ідеал, як ідеться у Гегеля і в класичній рефлексії культурі реалістичного зразка. Це культура, яка звертається до фактуального зрізу, за О. Лосєвим [1]. Адже такий зріз намагається бути мистецтвознавчим.

Артефакт несе в собі певне відлуння «арт» (англ. - мистецтво). Ми маємо елементарні намагання вбачати в мистецтві деструктурований об'єкт, який становить фактуальність наших співвідношень. Усі ці співвідношення, звичайно, не є однаково значимими, але вони тією чи іншою мірою засвідчують, що культура тяжіє до мистецької фактуальності. Це не факт феноменології, що його описав 
О. Лосєв як структурну, елементарну складову тетрактиди, не факт як самоданість речі у Е.Гуссерля. Це артефакт, тобто надфакт, факт, який набуває статусу культурної цілісності. Театральні синтези, які в культурі постмодерну досягають певного межового самовизначення, все більше й більше руйнують сам театр, все більше і більше досягати пластичної оптичної цілісності, притаманної зображувальним мистецтвам.

У 1961 році в нью-йоркському музеї сучасного мистецтва відбулася виставка мистецтва асамбляж, що містила в собі колажі і асамбляжі останніх кубістів, футуристів, сюрреалістів, реді мейдів Дюшана та ін.

Асамбляж стає достатньо синтетичною сферою візуальних мистецтв, яка вражає зображувальним інтегруючим витоком артефактів культури, що приходять з різних витворів мистецтва. У 60-ті роки XX століття виникають номінація «соціальний дизайн» та «арт-дизайн», що узагальнюють досвід системогенезу арт-практик постмодернізму.

Але їм притаманна дискретність фото, дискретна єдність як деструкція, тобто і артефакт, і асамбляж - це елементи деструктивного типу формотворення, в якому еклектика виникає як імпровізована сцена, нагнітання різних ритмів, як штучне маніпулювання різними несподіваними об'єктами, предметами і їх фрагментами. Усе це і є елемент того деструктивного бачення, яке постає як певне самознищення класичної культури.

В. Бичков певною мірою підсумовує таке розуміння деструктивного, дискретного, монтажного простору і зазначає, що воно не могло б бути можливим, якби не була розвинута певна низка інституцій менеджерської діяльності, котра теж входить у царину мистецьких практик постмодерну, створюючи той еклектичний симбіоз, який можливий як єднання різних цінностей, різного рівня образів, ідеалів та засадничих принципів.

Деякі сучасні елітарні співтовариства, зокрема власники художніх виставок, базуючись на засадах групування, створюють так звані галереї, організовують художні акції, які контрпозиціонують себе музеям традиційного типу. Галереї не є ретроархаїзуючою добіркою, хоча інколи і працюють на антикваріат. Їх експозиції не виникали історично, протягом кількох століть або, наприклад, наприкінці десятиліть останнього століття. Якщо йдеться про музеї XX століття, то це - живий архів, який поповнюється сучасними артефактами за контргалерейним принципом. Час, як певна парадигмальна 
надструктура або надсистема, дає можливість інколи назвати виставку музеєм, хоча ним вона не є у зв'язку з тим, що виникає певний ринок і потрібно регулювати експозиційну діяльність ринковими відносинами.

Складається певне коло людей, які стають арт-брокерами, бізнесменами, галерейниками, тими кураторами виставок, які «розкручують» імена, надають їм злету. I вся ця інфраструктура вже набуває планетарних ознак арт-ринку, який певною мірою $\epsilon$ деструктивним явищем. Адже тут не існує ніяких закономірностей, а $є$ певні імена як бренди, ознаки, але немає ані школи, ані змісту, ані якихось серйозних цінностей, до яких ми звикли в мистецтві. Уся ця реальність $є$ арт-діяльністю, має певну соціокультурну динаміку, є певною грою, що утворює своєрідний вербальний контекст, критику або псевдокритику, породжує рекламу, багатоярусний, розбитий на ієрархічні структури світ, який проголошує, що формується арт-номенклатура. Уся ця ідеологізована дійсність меншою мірою належить мистецтву, а здебільшого - бізнесу і дизайну як менеджменту і маркетингу, рекламі. Мистецтво поглинається бізнесом, більше того - розчиняється в ньому і стає одним із елементів функціонування товару, який зветься «художній витвір». Можна погодитися 3 думкою В. Бичкова, що мистецький праксис постмодерну стає нон-мистецтвом або не-мистецтвом [2].

Арт-ринок експлуатує зображувальність, видову специфіку, навіть жанрові складові мистецтва, але він все більше відходить від нього як такого, що створює образи, зображення і намагається ввійти в життя.

Ця псевдоілюзія, або псевдореальність, «демократизм» та трансвестія мистецтва, яке начебто вже є справжня реальність, дуже багато коштує тому мистецтву, яке так складно і так важко виборює себе.

Отже, як несподівано і як, так би мовити, некоректно відбуваються порівняння артефактів культури. Приблизно так само порівнювалися перші маніфести XX століття, коли «ангели на мотоциклах» здавалися більш кращими і яскравими, ніж ангели в небі. Уся ця гра в епатаж і артефакт як мистецько-фактуальне явище дійсності розгортається як постмодерна еклектика. I зараз ми не можемо підтвердити естетичну цінність тексту, твору чи їі спростувати.

Мистецтво завжди лишається вічним, не-мистецтвом або нонмистецтвом, образ єднання мистецтва і життя стає засадничим, фундаментальним принципом знищення мистецтва, його деконструкції. Отже, постмодерна еклектика формується за деструктивними 
засадами, в ній не відбувається симбіозу, того маньєризму, який виникає пізніше, як певна реальність (наприклад, нелінійна архітектура наприкінці XX століття). Важливо зазначити, що простір артефакту - це просторово-часовий континіум, в якому здійснюється буття або співбуття витворів сучасних арт-практик, арт-проектів.

Цей простір є дискретним, моделюється саме за принципами некласичної естетикиі, є несубстанційним, тобто він - релятивістський, конформний, ринково-трансформативний. Головне тут сама динаміка, яка утворюється глядачем. Так, наприклад, камера глядача у віртуальному фільмі чіпляється йому на голову, і він стає актуальним дієвим гравцем виникнення віртуального арт-простору. Приблизно ті самі просторові адеквації відбуваються в інших постмодерних трансформаціях, які можна назвати простором артефакту, тобто простору мистецтва та не-мистецтва, яке лише й визначається як послідовність дій, як єдність мистецького праксису. Простір артефакту постмодерну однаковою мірою $є$ деструктивним, синтетичним, поліморфним і належить царині деконструкції.

Тут можливі всі трансформації, усі реалії і всі диспозиції, які формуються як kompositio, як transpositio. Тобто позиції, які стають вихідними в просторі артефакту, є не дихотомічними, є не бінарною опозицією, а мінливим становленням того чи іншого визначення обрію чи елементу цього простору.

Такий простір і справді є динамічним - у ньому динаміка підноситься як потік, але не лише як потік свідомості, а й як потік безсвідомого. I вся ця психороблена нереальність певною мірою і належить і не належить мистецтву.

Арт-практики викреслюють час із постмодерних практик культури тому, що час тут девальвується, стає принципово не культурним, хоча культура скрізь визначається засадничим фундаментальним принципом. Час як історизм, як справжність цінностей не несе в собі ту культуру, яка є образом або ідеалом. Подається лише факт: артефакт як археологічний зріз, як шар, як феномен або шматок, уламок культури, який однаковою мірою $є$ і духовним, i бездуховним.

Саме по собі це засвідчує еклектизм бачення. Еклектика виникає тоді, коли простір домінує, а час як перспектива, як центрація, як коливання, як вічність усувається і замість нього існують певні догми або просторові схеми та концепти. Одним із найбільш зрежисованих та найбільш художньо осмислених є так званий енвайронмент - це із видів найбільш просунутих арт-практик останньої третини 
XX - початку XXI століть. Він повністю організований художником або колективом кураторів, інженерів, техніків, цілісним, неутилітарним арт-простором.

В енвайронменті набули завершення декілька тенденцій історичного розвитку мистецтва. Це передусім те, що походить своїми коріннями від глибокої давнини, традиції організації простору і середовища існування людини, що відбувається нерідко як достатньо стихійна єдність. Як правило, архітектори, декоратори інтер'єрів, садівники, діячі садово-паркового мистецтва, дизайнери, містобудівники на перше місце ставлять утилітарно-функціональні засади, за якими мета доповнюється естетичним уквітченням середовища існування. В останній третині XX століття організація естетичного середовища стала предметом важливих досліджень багатьох спеціалістів - містобудівників, теоретиків архітектури і дизайну, естетиків та ін.

Отже, енвайронмент буквально, як оточення середовищем, $\epsilon$ мистецтвом створення середовищного контексту. Це, за К.Фремптоном, один із останніх видів популізму в архітектурі, притаманний мистецтву постмодерну. Тобто мистецтво настільки входить у життя, у нього вже так багато артефактів, предметів мистецької реальності, що вони охоплюють весь простір навколо.

Енвайронмент - це певна єдність поп-арту, ленд-арту, мінімалізму, концептуалізму та інших реалій, реді мейдів. Для нього характерним є концептуалізм - певна дизайн-програма, ритуал або визначеність стратегії створення простору. Так, ленд-арт, тобто природні ландшафтні об'єкти, або дизайн інтер'єрів, ландшафтне середовище міста стають достатньо напруженим полем виявлення можливостей мистецьких впливів на середовище i, навпаки, впливу середовища на саме мистецтво. Мистецтво опосередковується тією субстанцією, яку помітив В. Глазичев, - натовпом.

Натовп теж створює середовище. Без цього феномену не можливе масове мистецтво. Він може бути цілком дискретним, розбитим за осередками, секціями своїх власних квартир, але згуртовується біля телеекрана, в одноманітних реакціях, клішованих жестах політикуму та ідеологем, міфологем сучасної культури. Останню можна називати масовою культурою, пост-культурою, нон-культурою, як завгодно, але тією чи іншою мірою їй притаманний мистецький праксис, тобто втручання мистецтва в життя як вміння, майстерності, тобто змагання 3 богами або з традицією і як вільного творчого оранжурування, 
що є одним із важливих принципів або складових енвайронменту.

Цікавим прикладом енвайронменту є декілька кварталів в Англії, в Лондоні, де вони раніше були суто промисловими, фабричними забудовами. Потім їх викупили багаті люди, залишили зовнішність суто такою, якою вона була (цегла задимлена, збережені труби фабричних заводів, які нагадують Тауер), а середину наситили вже сучасним супер-інстальованим простором інтер'єру, який відповідає всім вимогам комфортного життя.

Виникає несподіване, виникає єдність або надсистема, в якій традиція як зберігання зовнішнього середовища поєднується зі зміною функцій. Фактично саме функціональне зонування, зміна функцій відбуваються як певна режисура, як мода. Нині ці квартири - найдорожчі в Англії. Чому? Тому, що продається історія, продається як зразок мистецького праксису, який є активним втручанням у середовище, більше того, перевтіленням середовища, трансформацією його, утворенням абсолютно несподіваних конфігурацій, які поєднують в собі необруталізм, віртуальність як наслідування традиції і штучне кіборгове зомбування людини, яка існує в цьому просторі.

Еклектика, за мірками старого культурницького монізму, який існував у XIX столітті, переростає в еклектику безмірного, в еклектику безструктурного, в еклектику хаосогенної трансформації, яка несе в собі безлад, безмежність різних практик і неможливість їх єднання в контексті реалій будь-яких змістів, семантик та семантичних світів. Розширення естетичного бачення навколишнього середовища сприяло залученню до неї архітектури, інтер'єру, міського індустріального ландшафту.

Визначення естетичності навколишнього середовища виникало порівняльно пізно. Енвайроментальна естетика включає в себе оцінювання енвайромента і мистецтва навколишнього середовища. Зміни природного ландшафту, пов'язані зі зростанням урбанізації, поглиблюють осмислення його цінностей. Відтак ландшафт починають розглядати як цілісний феномен, котрий має суспільне значення, що підлягає зберіганню.

Те саме стосується і естетичних особливостей урбанізму, які визначаються водночас з економічним плануванням, обладнанням території і використанням природних ресурсів. Ми бачимо, що мистецькі практики постмодерну в їх середовищному, предметно-діяльнісному вигляді не є суто хепенінг, безлад чи певні ігрові проекцій, 
або театр проективних тіней. Це більшою мірою достатньо функційна естетика, пов'язана $з$ енвайронментом, у буквальному розумінні це естетика середовищна, промислово-прикладна, комунікативна.

Естетика середовища відразу ж загострює проблеми епіцентрів, креативних витоків, точок середовища, які $є$ надцінністю, яку потрібно зберігати, бо вони містять у собі мистецтво, культуру, людяність як таку.

Якщо розглянути місто як об’єкт діяльності дизайнера, то будь-яке історичне місто має декілька шарів просторових реалій. Так, в екстенсійному вимірі, по горизонталі воно окреслюється поняттям «ландшафт» і поняттям «силует міста», а зонування на культурно-історичні зони надає візуальним характеристикам ознаки вічного, тимчасового і динамічного середовища. По вертикалі місто немов несе в собі час. Ми знаємо, що археологічні шари, які $\epsilon$ найскладнішими, найтемнішими образними конфігураціями минулого, інколи стають відкриттям.

Естетика енвайронменту певною мірою є естетикою відкриття і експерименту, а також проективною. Уся ця, так би мовити, еклектична реальність потребує певної терплячості, певного консенсусу, гармонізації конфліктів онтологій бачення, онтологій трансформацій дійсності, втручання в цю дійсність, онтологій екологічних. Насамперед важливо зрозуміти, що мистецький праксис набирає системних або надсистемних ознак у контексті формування великих систем - міст, транспортних артерій, рекламних агломерацій та ін.

Занурення, міфологізація, входження в минуле як певна інтроверсія часу і простору створює еклектику, яка є моністичною, але цей монізм вже позаіманентний, позаструктурний. Він виходить за структури мистецького твору і $є$ суто ідеологічно-комерційним. Комерційний присмак постмодерністської культури $є$ настільки наявним, що про це вже й не варто вести мову.

Як бачимо, коливання еклектичного симбіозу досить різне - від середовищно-екологічного до середовищно-епатувального, театралізованого, що пов'язано з перформансами і хепенінгами, і навіть 3 політизовано-ідеологічними субструктурами, які певний час використовуються як певні інсталяції і заповідники тоталітаризму. Вони немовби дають можливість увійти у концтабір знаково-символічних категорій та образів. Увесь цей ідеологічний симбіоз, уся ця площина надзвичайно цікава саме в контексті культуротворчості. Виникає культура або тотальної мімікрії, або тотального популізму. 
Усе це надзвичайно важливо зрозуміти - не просто як мінливість $\mathrm{i}$ зміни, а як рух від однієї світової осі до іншої, які деколи зустрічаються в постмодерній культурі. Такі світові осі можна позначити різними номінаціями і категоріями - як нетрадиційний сакральний топос або як уламки суб'єкта класики. Це можуть бути оптичні ретроспекції, котрі буквально наслідують оптику великих стилів (Biдродження, Барокко). Це можуть бути міфологеми, міфи (штучні міфи, рефлективні, соціальні), які теж створюють свої креативні епіцентри, що надають можливість подати візуальну цілісність як феномен формотворчості і феномен культуротворіння.

\section{ЛІТЕРАТУРА}

1. Лосев А.Ф. Форма. Стиль. Выражение. - М., 1995. - 944 с.

2. Бычков В.В. Эстетика. - М., 2002. - 556 [4] с.

3. Джеймісон $\Phi$. Постмодернізм або логіка культури пізнього капіталізму : Пер. $з$ англ. Петра Дениска. - К., 2008. - 504 с.

Барна Н.В. Генеративні тендениії дизайну в контексті техноінновачій постмодерну.

У статті доводиться, що тотальна еклектика постмодерну, моністична еклектика протомодерну $є$ в принципі тотожними. Такими $є$ й монізм тотального плюралізму, і монізм орнаментального дифузного дискретного колажу. Маємо зрозуміти, що еклектика середини XIX століття, еклектика як завершення постмодерного праксису - це $\epsilon$ один і той самий тип, який визначається в культурі як маньєризм. Він може мати різні ознаки, різні феноменологічні конфігурації, але його сутність полягає в тому, що це симбіоз, це еклектика, це надсистема, це трансформація попередніх систем, коли не одна, а кілька систем стають елемантами в загальному поєднанні композиційної єдності і коли виникає саме те, що ми називаємо симбіозом.

Ключові слова: мистецтво, постмодерн, дизайн, художня культура, естетика.

Барна Н.В. Генеративные тенденщии дизайна в контексте техноинноваций постмодерна.

В статье доказывается, что тотальная эклектика постмодерна, монистическая эклектика протомодерну в принципе тождественны. Такими являются и монизм тотального плюрализма, и монизм орнаментального диффузного дискретного коллажа. Мы должны понять, что эклектика сере- 
дины XIX века, эклектика как завершение постмодернистского праксиса это один и тот же тип, который определяется в культуре как маньеризм. Он может иметь различные признаки, различные феноменологические конфигурации, но его сущность заключается в том, что это симбиоз, это эклектика, это надсистема, это трансформация предыдущих систем, когда не одна, а несколько систем становятся елемантамы в общем сочетании композиционного единства и когда возникает именно то, что мы называем симбиозом.

Ключевые слова: искусство, постмодерн, дизайн, художественная культура, эстетика.

Barna N. Generative design trends in the context of postmodern technoinnovation.

We came to the Rubicon of our considerations when you generalize and say that the total eclectic postmodern eclecticism monistic protomodernu are basically identical. Monism total monism and pluralism diffuse discrete ornamental collage is also identical. We understand that the mid-nineteenth century eclecticism, eclectic postmodern praxis as the end - it's the same type, defined culture as mannerism. It can have different symptoms, different phenomenological configuration, but its essence is that this symbiosis is eclectic, it nadsystema, this transformation of previous systems where more than one system, and several systems are elemantamy the total combination of compositional unity and when there is what we call symbiosis.

Key words: art, postmodern, design, art and culture, aesthetics. 